\title{
Robo1 and Robo2 Control the Development of the Lateral Olfactory Tract
}

\author{
Coralie Fouquet, ${ }^{1,2}$ Thomas Di Meglio, ${ }^{1,2}$ Le Ma, ${ }^{4}$ Takahiko Kawasaki, ${ }^{3}$ Hua Long, ${ }^{4}$ Tatsumi Hirata, ${ }^{3}$ \\ Marc Tessier-Lavigne, ${ }^{3}$ Alain Chédotal, ${ }^{1,2}$ and Kim T. Nguyen-Ba-Charvet ${ }^{1,2}$ \\ ${ }^{1}$ Centre National de la Recherche Scientifique and ${ }^{2}$ Université Pierre et Marie Curie-Paris 6, Unité Mixte de Recherche 7102, Paris, 75005 France, ${ }^{3}$ Division \\ of Brain Function, National Institute of Genetics, Graduate University for advanced Studies (Sokendai), Yata 1111, Mishima 411-8540, Japan, and ${ }^{4}$ Howard \\ Hughes Medical Institute, Department of Biological sciences, Stanford University, Stanford, California 94305
}

The development of olfactory bulb projections that form the lateral olfactory tract (LOT) is still poorly understood. It is known that the septum secretes Slit1 and Slit2 which repel olfactory axons in vitro and that in Slit1 ${ }^{-/-}$;Slit2 ${ }^{-/-}$mutant mice, the LOT is profoundly disrupted. However, the involvement of Slit receptors, the roundabout (Robo) proteins, in guiding LOT axons has not been demonstrated. We show here that both Robo1 and Robo2 receptors are expressed on early developing LOT axons, but that only Robo2 is present at later developmental stages. Olfactory bulb axons from $\mathrm{Robol}^{-1-} ; \mathrm{Robo}^{-/-}$double-mutant mice are not repelled by Slit in vitro. The LOT develops normally in $\mathrm{RoboI}^{-/-}$mice, but is completely disorganized in $\mathrm{Robo}^{-/-}$and $\mathrm{Robol}^{-/-} ; \mathrm{Robo2}^{-/-}$double-mutant embryos, with many LOT axons spreading along the ventral surface of the telencephalon. Finally, the position of lot1-expressing cells, which have been proposed to be the LOT guidepost cells, appears unaffected in Slit ${ }^{-/-}$;Slit ${ }^{-/-}$mice and in Robo $^{-1-}$;Robo $2^{-/-}$mice. Together, our results indicate that Robol and Robo2 directly mediate the repulsive activity of Slit receptors on LOT axons, and are required for normal guidance of these axons in vivo.

Key words: chemorepulsion; olfactory bulb; Slit; roundabout; axon guidance; midline

\section{Introduction}

The development of axonal projections has been studied extensively in the olfactory system. Olfactory neurons from the olfactory epithelium send their axons to specific glomeruli in the main olfactory bulb (OB), where they synapse on the dendrites of mitral and tufted cells. These OB neurons then project to the primary olfactory cortex (Schwob and Price, 1984; Shipley and Ennis, 1996; Zou et al., 2001). OB axons are positioned laterally, under the pial surface, and constitute the lateral olfactory tract (LOT). The first mitral cell axons leave the $\mathrm{OB}$ at embryonic day 12.5 (E12.5) in mice and the LOT is discernible the following day (Pini, 1993; Sugisaki et al., 1996). Organotypic cocultures of OB and telencephalic vesicles or cell membranes have suggested that LOT axons are guided by short-range cues distributed along their pathway on guidepost cells called "lot" cells (Sugisaki et al., 1996; Hirata and Fujisawa, 1997). Moreover, LOT axons were also shown to be repelled in vitro by diffusible factors secreted by the olfactory epithelium, septum, and olfactory cortex (Pini, 1993; $\mathrm{Hu}$ and Rutishauser, 1996; de Castro et al., 1999). Thus, the path-

Received Nov. 6, 2006; revised Feb. 13, 2007; accepted Feb. 14, 2007.

This work was supported by a grant from the Association pour la Recherche sur le Cancer to A.C. We thank Dr. Yumiko Saga (National Institute of Genetics, Mishima Japan) for providing the gene-trap mouse line.

Correspondence should be addressed to Alain Chédotal, Centre National de la Recherche Scientifique Unité Mixte de Recherche 7102, Université Pierre et Marie Curie, Equipe Développement Neuronal, Case 12,9 quaiSaint-Bernard 75005 Paris, France. E-mail: alain.chedota@@snv.jussieu.fr.

L. Ma's present address: Department of Cell and Neurobiology, Zilkha Neurogenetic Institute, University of Southern California, Los Angeles, CA 90089.

M. Tessier-Lavigne's present address: Genentech, 1 DNA Way, South San Francisco, CA 94080

D0I:10.1523/JNEUROSCI.0172-07.2007

Copyright $\odot 2007$ Society for Neuroscience $\quad$ 0270-6474/07/273037-09\$15.00/0 finding of LOT axons in the telencephalon involves a combination of short- and long-range cues. We have shown previously that the septum-derived repellents for LOT axons are two Slit proteins, Slit1 and Slit2 (Nguyen Ba-Charvet et al., 1999, 2002), but the receptor(s) mediating Slit function in this system have not been fully defined.

The major functional receptors for Slits are members of the roundabout (Robo) receptors. The first roundabout gene, Robo, was identified in Drosophila in a screen for genes regulating midline crossing in the CNS (Seeger et al., 1993). Three Robo genes have been found in Drosophila (Kidd et al., 1998; Rajagopalan et al., 2000a; Simpson et al., 2000b) and mammals (Brose et al., 1999; Li et al., 1999; Yuan et al., 1999; Jen et al., 2004), and one in Caenorhabditis elegans (Zallen et al., 1998). Mammalian Slits can bind to all Robo receptors with comparable affinity (Brose et al., 1999; Li et al., 1999; Sabatier et al., 2004). Robo proteins belong to the Ig superfamily and have five Ig-like domains followed by three fibronectin type III repeats, a transmembrane portion and an intracellular tail containing conserved cytoplasmic motifs. Another protein, Robo4, containing the first two Ig domains has been found only expressed by endothelial cells and plays a role in angiogenesis (Huminiecki et al., 2002; Bedell et al., 2005), but its ability to bind Slit is debated (Suchting et al., 2005). The involvement of Robo receptors in Slit signaling in vivo has been well demonstrated in invertebrates (Kidd et al., 1998; Rajagopalan et al., 2000a,b; Simpson et al., 2000a), in the spinal cord of vertebrates (Sabatier et al., 2004), and in C. elegans (Hao et al., 2001). We show here, using in vitro assays, binding studies, and the phenotypic analysis of Robol and Robo2 mouse knock-outs, that 
Robol and Robo2 are the receptors mediating Slit repulsive action on LOT axons.

\section{Materials and Methods}

Swiss mice (Janvier, Le Genest Saint Isle, France) were used for binding studies. Slitdeficient mice and Robo-deficient mice were described previously and genotyped by PCR (Plump et al., 2002; Grieshammer et al., 2004; Long et al., 2004) (L. Ma and M. TessierLavigne, unpublished observation). To better visualize LOT axons, Slit1;Slit2 mutant mice were crossed to the ERE mouse line, a trap line in which the lac $Z$ reporter gene was randomly inserted into the genome (a gift from Y. Saga, National Institute of Genetics, Mishima, Japan). The insertion site is still unknown. The day of the vaginal plug was counted as E0 and the day of the birth as postnatal day 0 (P0). Mice were anesthetized with sodium pentobarbital $(50 \mathrm{mg} / \mathrm{kg})$. All animal procedures were performed in accordance with institutional guidelines.

Generation of LRR2-hSlit1-AP and LRR2hSlit2-AP. To generate the human leucine-rich repeat (LRR) Slit1/2-alkaline phosphatase (AP) fusion proteins (LRR2-hSlit1-AP or LRR2hSlit2-AP), the second LRR of Slit1 (amino acids 282-512) or Slit2 (amino acids 341-505) was amplified by PCR and cloned between the $X h o I$ and $X b a I$ sites of the AP-Tag5 vector (GenHunter, Nashville, TN).

Binding studies. Human embryonic kidney 293 cells were transfected with LRR2-hSlit1/ 2-AP using Lipofectamine 2000 reagent (Invitrogen, Carlsbad, Ca) and grown for $48 \mathrm{~h}$. The supernatant was used directly without additional purification. AP activity was measured as described previously (Flanagan and Leder, 1990) and the presence of the fusion protein in the supernatant confirmed on Western blot with an anti-AP antibody (1:6000; GenHunter). A single band at the expected molecular weight 100 KDa was detected (data not shown).

Binding was performed as described by Kolodkin et al. (1997). Briefly, $20 \mu \mathrm{m}$ cryosections (from fresh-frozen brains) were fixed for $8 \mathrm{~min}$ in cooled $100 \%$ methanol. The sections were then washed three times in PBS, $4 \mathrm{~mm}$ $\mathrm{MgCl}_{2}$, and incubated in a blocking solution (PBS, $4 \mathrm{mM} \mathrm{MgCl}_{2}, 10 \%$ fetal bovine serum; Invitrogen) for $1 \mathrm{~h}$ at room temperature (RT). Four-hundred microliters of LRR2-hSlit1/2-AP supernatant, diluted 1/5 in PBS, were added to the sections and incubated for $2 \mathrm{~h}$. After five washes in $4 \mathrm{mM} \mathrm{MgCl}_{2}$ in PBS at RT, sections were fixed for 2 min with $60 \%$ acetone, $4 \%$ paraformaldehyde, and $20 \mathrm{~mm}$ HEPES, $\mathrm{pH} 7$. After five additional washes in PBS, the sections were incubated at $65^{\circ} \mathrm{C}$ for $2 \mathrm{~h}$ in PBS to inactivate endogenous phosphatases. Sections were washed twice in PBS and incubated in 100 mм Tris, $\mathrm{pH}$ 9.5, $100 \mathrm{~mm} \mathrm{NaCl}$, and $5 \mathrm{~mm} \mathrm{MgCl}_{2}$ for $5 \mathrm{~min}$. Last, the slides were incubated for $2 \mathrm{~h}$ at RT in $100 \mathrm{~mm}$ Tris, $\mathrm{pH} 9.5,100 \mathrm{~mm} \mathrm{NaCl}$, and $5 \mathrm{mM} \mathrm{MgCl}_{2}$, containing $300 \mu \mathrm{g} / \mathrm{ml}$ nitroblue tetrazolium (NTB; Roche, Meylan, France) and $250 \mu \mathrm{g} / \mathrm{ml}$ 5-bromo-4-chloro-3-indolyl phosphate (BCIP; Roche).

Immunocytochemistry. Until E16, embryos were fixed by immersion in $4 \%$ paraformaldehyde (PFA) in $0.12 \mathrm{~m}$ phosphate buffer, $\mathrm{pH}$ 7.4. Older mice were perfused transcardially with $4 \%$ PFA, postfixed for $3 \mathrm{~h}$, and then cryoprotected in $10 \%$ sucrose. Cryostat sections were blocked in $0.2 \%$ gelatin in PBS containing $0.25 \%$ Triton X-100 and incubated overnight at RT with goat anti-neuropilin 1 (NP1; R \& D Systems, Minneap- olis, MN), rat anti-L1 (Millipore, Temecula, CA), goat anti-Robol (R \& D Systems), goat anti-Robo2 (R \& D Systems), rabbit anti-Robo2 (a gift from Dr. Murakami, Osaka, Japan) (Sabatier et al., 2004), goat antiRobo3 ( $\mathrm{R} \& \mathrm{D}$ Systems), rabbit anti- $\beta$-galactosidase (MP Biomedicals, Irvine, CA), and rat mAb Lot1 (Sato et al., 1998), followed by speciesspecific secondary antibodies directly conjugated to fluorophores [cy-3 (Jackson ImmunoResearch, West Grove, PA) or Alexa Fluor (Invitrogen)]. Sections were examined under a fluorescent microscope (DMR; Leica, Nussloch, Germany).

PLAP staining. Cryostat section, pretreated just as for immunocytochemistry, were incubated $30 \mathrm{~min}$ in $\mathrm{PBS}$ at $65^{\circ} \mathrm{C}$, buffered $10 \mathrm{~min}$ in $\mathrm{B} 3$ buffer $\left(0.1 \mathrm{~m}\right.$ Tris, pH 9.5, $\left.0.1 \mathrm{M} \mathrm{NaCl}, 50 \mathrm{~mm} \mathrm{MgCl}_{2}\right)$. We then detected human placental alkaline phosphatase (PLAP) activity with $0.1 \mathrm{mg} / \mathrm{ml}$ $\mathrm{BCIP}$ and $1 \mathrm{mg} / \mathrm{ml} \mathrm{NBT}$ in B3 buffer. PLAP-stained tissue was then washed in PBS and mounted in Mowiol (Calbiochem, La Jolla, CA).

$X$-Gal staining. ERE mouse is a gene-trap line isolated from the random insertion series of the $\beta$-galactosidase gene into the mouse genome performed by Dr. Yumiko Saga at the National Institute of Genetics in 

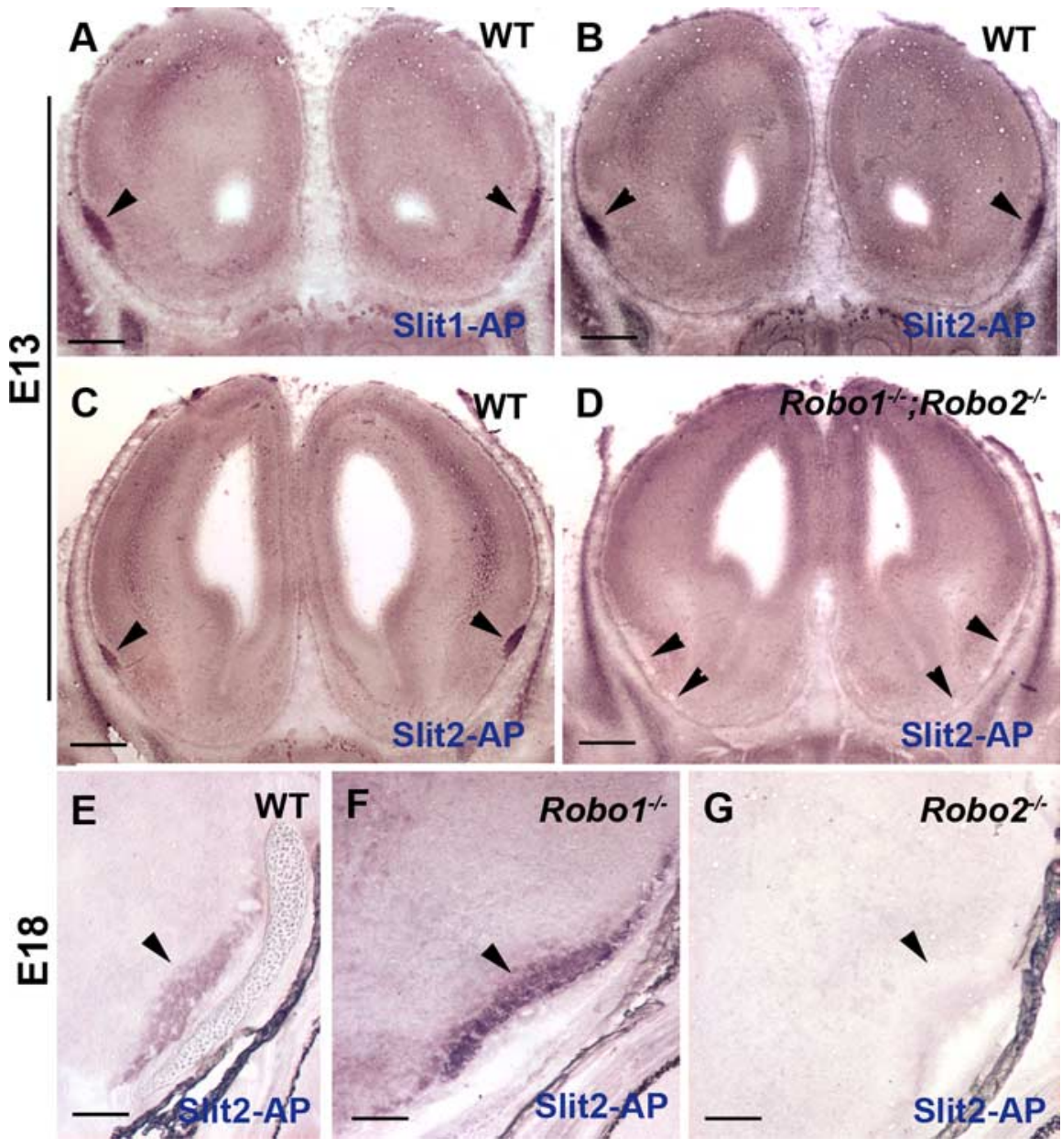

Figure 2. LRR2-hSlit-AP binding to LOT axons. A-G, LRR2-hSlit1-AP (Slit1-AP) and LRR2-hSlit2-AP (Slit2-AP) proteins were applied to E13 $(\boldsymbol{A}-\boldsymbol{D})$ or E18 $(\boldsymbol{E}-\boldsymbol{G})$ forebrain coronal sections at the level of the LOT. $\boldsymbol{A}, \boldsymbol{B}$, Both Slit1-AP and Slit2-AP bind to the LOT (arrowheads). C, D, Slit2-AP binding is only observed on LOT axons from wild-type mice (WT; $C$, arrowheads) and not on defasciculated LOT axons from Robo1;Robo2 double mutants ( $\boldsymbol{D}$, arrowheads). $\mathbf{E}-\mathbf{G}$, At E18, Slit2-AP still strongly binds to L0T axons (arrowheads) from WT $(\boldsymbol{E})$ and Robo $1^{-1-}$ mice $(\boldsymbol{F})$, but not on LOT axons from Robo2 $2^{-1-}$ mice (G). Scale bars: $\boldsymbol{A}-\boldsymbol{D}, 560 \mu \mathrm{m} ; \boldsymbol{E}-\boldsymbol{G}, 60 \mu \mathrm{m}$.

Japan. The brains of the embryos were dissected and stained using X-Gal by the method of Saga et al. (1992). In the line, most, if not all, of the main olfactory projection neurons were found expressing $\beta$-galactosidase (T. Kawasaki and T. Hirata, unpublished observation).

Repulsion assay. OB explants from E14.5 Robo-deficient, heterozygous, and wild-type littermate embryos were cocultured in collagen gels with aggregates of Slit2-transfected COS-7 cells [transformed African green monkey kidney fibroblast cells (COS cells)] or floor-plate cells from E13 rat embryos as described previously (Nguyen Ba-Charvet et al., 1999). Explants were cultured in neurobasal medium supplemented with B27 for $48 \mathrm{~h}$. At the end of this period, explants were fixed in ice-cold $4 \%$ PFA and immunostained with a neuron-specific anti-class III $\beta$-tubulin monoclonal antibody (TuJ-1; Covance, Berkeley, CA) for visualization of the axons.

DiI tracing. The olfactory bulb of E16 to E18 embryos was injected with the lipophilic tracer $1,1^{\prime}$-dioctadecyl-3,3,3', $3^{\prime}$-tetramethylindocarbocyanine perchlorate (DiI; Invitrogen) as described previously (de Castro et al., 1999).

\section{Results}

Robol and Robo2 are expressed in the lateral olfactory tract

To determine whether LOT axons expressed Robo receptors, we first performed an immunohistochemical study. At E13, LOT axons were strongly immunoreactive for Robo2, consistent with our previous in situ hybridization data (Nguyen Ba-Charvet et al., 1999; Marillat et al., 2002) (Fig. 1A). Interestingly, E13 LOT ax- ons were also immunoreactive for Robol (Fig. $1 B$ ). Neither Robo1 nor Robo2 were expressed on so-called lot cells (see below). Double immunolabeling revealed that Robol is expressed by a subset of Robo2-positive LOT axons (Fig. 1C). This expression pattern was unchanged until E15 (data not shown). From E16, we were unable to detect Robol protein on LOT axons (Fig. $1 D$ ), visualized with an anti-L1 antibody (Fig. 1E,F,H,I) (Inaki et al., 2004), whereas Robo2 was still highly expressed (Fig. $1 G$ ). In Robo1-deficient mice, a cassette encoding $\beta$-galactosidase ( $\beta$-gal) and PLAP was inserted in the Robol locus (Long et al., 2004). Similarly, $\beta$-galactosidase-fused with tau was inserted into the Robo2 locus (Grieshammer et al., 2004). At E16, neither $\beta$-galactosidase, nor PLAP could be detected in the LOT of Robo1 $1^{+/-}$mice, whereas $\beta$-gal was expressed in the LOT of Robo $2^{+/-}$ mice (data not shown). In contrast, $\beta$-gal was not expressed by lot cells. Robo3/Rig1 (retinoblastoma inhibiting gene 1) expression was never detected on LOT axons (data not shown). Overall, these results show that early developing LOT axons coexpress Robo 2 and Robo1, whereas only Robo 2 is expressed on older LOT axons.

\section{LRR2-hSlit bind to LOT axons}

A previous structure-function analysis of the LRR domains of Drosophila Slit (Howitt et al., 2004) revealed that the active site of Slit is located on the second of the four LRR (LRR2), which is highly conserved between Slits (Howitt et al., 2004). To attempt to visualize Slit binding sites in the developing mouse brain we generated two fusion proteins consisting of LRR2hSlit1 or LRR2-hSlit2 (see Materials and Methods) fused to AP and performed binding studies. We found that at E13-E18, both LRR2-hSlit1-AP and LRR2-hSlit2-AP strongly bound to LOT axons (Fig. 2A-C,E). To determine if Slit-AP constructs selectively bound to Robo receptors, we next performed binding on $\mathrm{OB}$ and forebrain sections from E13 and E18 Robo1 and Robo2 single and double mutants (see Materials and Methods). We used LRR2hSlit2-AP, because it is more highly expressed by transfected cells than LRR2-hSlit1-AP. At E13, LRR2-hSlit2-AP binding to LOT axons was observed in Robo1 and Robo2 single mutants, but not in Robo1;Robo2 double mutants (Fig. 2D) (data not shown). At E18, LRR2-hSlit2-AP binding was still intense in wild-type and Robo1 $^{-1-}$ LOT axons (Fig. 2 E, F), but was absent in Robo2 ${ }^{-/-}$or Robo1 $^{-/-}$;Robo2 $2^{-/-}$LOT axons (Fig. $2 G$ ) (data not shown). At no time did LRR2-hSlit2-AP bind to LOT cells. These results confirm the immunocytochemical data, and also show that Robol and Robo2 are most likely the only major Slit receptors on LOT axons (see Discussion).

\section{Slits do not repel OB axons from Robo $^{-/-} ;$Robo $^{-/-}$ mutant mice}

We next examined whether $\mathrm{OB}$ axons from mice deficient for both Robo1 and Robo2 could still respond to Slit chemorepulsive 
activity. We used E14 OB explants from wild-type, Robo1 $1^{+/-} ; R_{o b o 2^{+/-}}$, or Robo1 ${ }^{-/-} ; R o b o 2^{-/-}$mutant mice, and cultured them for $24-36 \mathrm{~h}$ in collagen gels adjacent to explants of spinal cord floor plate, which is a source of Slit proteins ( $\mathrm{Hu}$ and Rutishauser, 1996; Hu, 1999) or adjacent to COS cell aggregates expressing Slit2. OB axons were visualized after immunostaining with anti-class III $\beta$-tubulin monoclonal antibody TuJ-1, a pan-neuronal marker. As described previously (Nguyen Ba-Charvet et al., 1999), very robust repulsion was observed, with OB axons growing away from the Slit2secreting COS cells [with a proximal/distal ratio (see Materials and Methods) of $0.196 \pm 0.08$ (SEM), from six explants] (Fig. $3 E)$ or floor plate explants $(0.229 \pm$ 0.09 , from eight explants) (Fig. $3 B$ ). The behavior of $\mathrm{OB}$ axons from Robol ${ }^{+/-}$; Robo2 ${ }^{+/-}$mice was similar to that of controls, whether the chemorepulsive activity was from floor plate $(0.245 \pm 0.12$, from four explants) (Fig. $3 G$ ) or from Slit2secreting COS cells $(0.313 \pm 0.16$, from four explants) (Fig. $3 H$ ). In contrast, the repulsion was virtually abolished with $\mathrm{OB}$ explants from $\mathrm{Robo1}^{-/-}$;Robo2 $2^{-/-}$mice adjacent to floor-plate explants (0.993 \pm 0.31, 10 explants from three distinct double mutants) or Slit2-secreting aggregates $(1.12 \pm 0.1$, nine explants from three distinct double mutants) (Fig. 3C,F). Together, these results indicate that the repulsive responses of $\mathrm{OB}$ axons to Slit proteins in vitro requires Robol and Robo2 receptors.

LOT axon defects in Slit1:Slit2 and Robo1;Robo2 mutant mice We observed previously that the LOT is very disorganized in Slit1;Slit2 double-mutant mice, consistent with a role in mediating septal repulsion in vivo (Nguyen-Ba-Charvet et al., 2002). To confirm the involvement of Robo receptors in LOT guidance in vivo, we next analyzed LOT development in Robo1 and Robo2 single- and double-mutant mice. DiI injections in the olfactory bulb of E15 to E18 embryos in wild-type mice $(n=5)$ (Fig. $4 A$ ) always lead to the anterograde tracing of a single axon tract that runs rostrocaudally just under the pial surface, which corresponds to the LOT. We observed the same phenotype using different LOT markers, such as the anti-L1 antibody, which has been shown to label all LOT axons and an antibody against neuropilin-1, which is expressed by all LOT axons, except the deepest ones (Inaki et al., 2004). Both antibodies reveal a thick LOT axon bundle in the lateral telencephalon of wild-type animals (Fig. 5A-C). In Robo1 ${ }^{-/-}$mutant mice (seven of seven cases) or Robo1 ${ }^{+/-}$;Robo2 ${ }^{+/-}$mutant mice (nine of nine cases), the LOT ran normally as a thick axon bundle similar to wild-type (Figs. 4B, C, 5D-F). Nevertheless, in most Robo1 ${ }^{-1-}$ mice, the LOT was slightly enlarged (six of seven cases). In contrast, in Robo2 $2^{-/-}$mice (two of two cases), the LOT was thinner and spread along the ventrolateral surface of the telencephalon (Figs. $4 D, 5 G-I)$, although they still respect their normal dorsal bound-

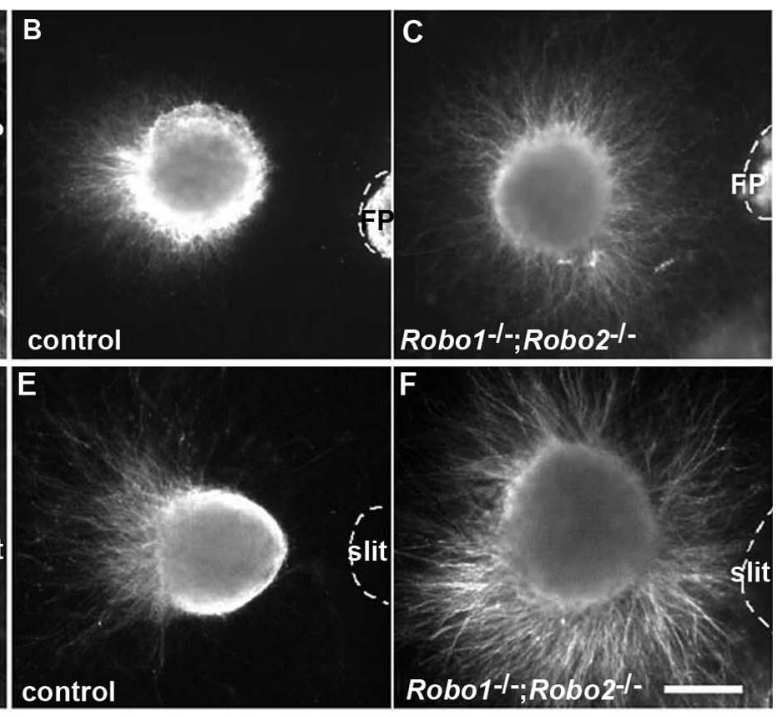

Floor plate

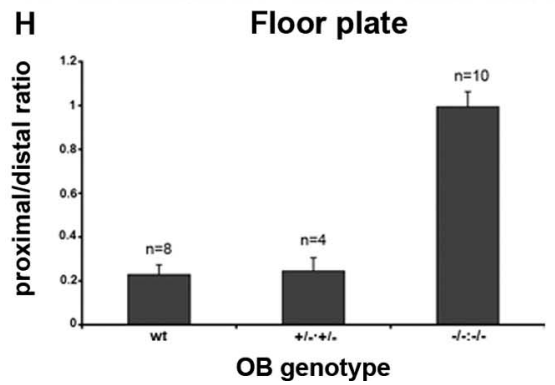

OB genotype

Figure 3. Olfactory axons from $R o b o 1^{-1-} ; R o b 02^{-1-}$ mutant are not repelled by Slit2-expressing cells. $\boldsymbol{A}-\boldsymbol{C}$, Olfactory bulb explants from wild-type $(\boldsymbol{A}, \boldsymbol{B})$ or Robo1 $1^{-/-} ; R o b 02^{-/-}$E14 mice were cultured with floor plate (FP) explants ( $\left.\boldsymbol{B}, \boldsymbol{C}\right)$ from E13 rat embryos. Wild-type $O B$ axons grow radially in absence of $F P(A)$ but are strongly repelled by $F P(B)$. In contrast, axons from OB are not repelled by $F P(C)$. D-F, Wild-type $O B$ axons grow radially in front of control COS cells but are repelled by Slit2-expressing $\operatorname{COS}$ cells $(\boldsymbol{D}, \boldsymbol{E})$. $\boldsymbol{F}$, In contrast, Robo1; Robo2-deficient axons are not repelled by Slit2-expressing cells. $\boldsymbol{G}, \boldsymbol{H}$, Quantification of the repulsion assay. Scale bar: (in $\boldsymbol{F}$ ) $\boldsymbol{A}-\boldsymbol{F}, 150 \mu \mathrm{m}$. Error bars indicate SEM.

ary. These defects were even more striking in Robol $^{-/-} ;$Robo $^{-/-}$ mice (seven of seven cases) at E15.5 (data not shown) as well as at E18: the LOT was very defasciculated into small axonal bundles fanned all over the ventral side of the telencephalon (Fig. 4E,F). On coronal forebrain sections from $\mathrm{Robo1}^{-/-} ; \mathrm{Robo}^{-/-}$mice, L1-positive axons as well as NP1-positive axons were divided into multiple small bundles scattered from the initial LOT lateral position to the ventral midline (Fig. $5 J, K$ ). This phenotype was the same as described previously in Slit $1^{-/-} ;$Slit $2^{-/-}$mice (NguyenBa-Charvet et al., 2002). Interestingly, in $\mathrm{Robo1}^{-1-}$;Robo2 $2^{-1-}$ mice, a subset of LOT axons, originating from the lateral OB, were still present at their normal position (Fig. $5 J-L$ ). This heterogeneous behavior of medial/lateral LOT axons was even more striking in Slit $1^{-/-}$;Slit $2^{-/-}$mice injected with DiI in the OB or that expressed $\beta$-galactosidase in LOT axons (see Materials and Methods) (Figs. 6, $7 A-D)(n=2)$. Again, medial OB axons were more severely affected than lateral ones. This also confirmed that LOT axons were specifically misrouted ventrally, but still respect their dorsal boundary. Together, these results show that the pathfinding of the LOT axons, in particular those originating from the medial OB, is profoundly disrupted in $\mathrm{Robo2}^{-1-}$ and $\mathrm{Robol}^{-1-}$; Robo2 $2^{-1-}$ mutant mice.

\section{Lot cell pattern is not perturbed in Slit- or}

Robo-deficient mice

It has been shown previously that LOT axons may be guided through short-range interaction with so-called "lot cells," which 

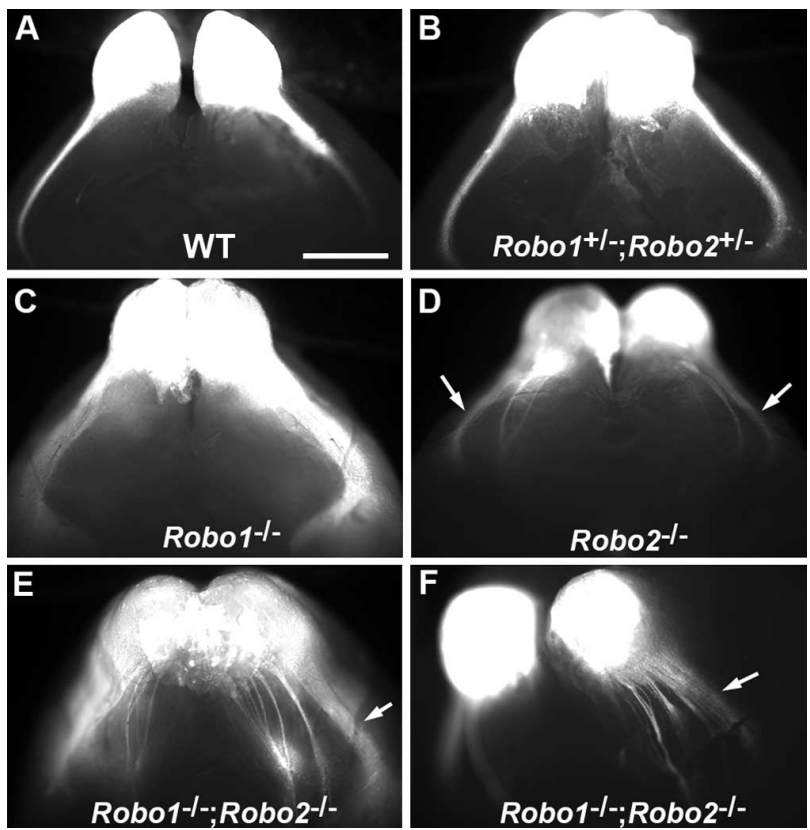

Figure 4. Ventrolateral views of whole-mount brains from Robo-deficient mice at E18 showing the localization of the LOT. $A, B$, Embryos were injected in the OB with Dil. The LOT extends caudally and laterally along the pial surface of the telencephalon, forming a single axon bundle in wild-type brain (A) but also Robo $1^{+/-} ;$Robo2 $2^{+/-}$mice (B). C, D, In Robo1 ${ }^{-/-}$mutants, the LOT spreads slightly at the surface $(\boldsymbol{C})$, and in $R o b o 2^{-1-}$ mice $(\boldsymbol{D})$, little LOT ectopic fascicles are observed ventrally. $\boldsymbol{E}, \boldsymbol{F}, \operatorname{In} R o b 01^{-1-}$ Robo2 $2^{-1-}$ mice, $\mathrm{OB}$ axons are highly defasciculated along on the ventral side of the brain. Note that in $R_{0 o b 02^{-/-}}(\boldsymbol{D})$ and $R o b o 1^{-1-} ; R_{0 b 02^{-1-}}$ mice $(\boldsymbol{E}, \boldsymbol{F})$, a subset of $O B$ axons are still at their correct position (arrows). Scale bar: (in $A) A-F, 575 \mu \mathrm{m}$.
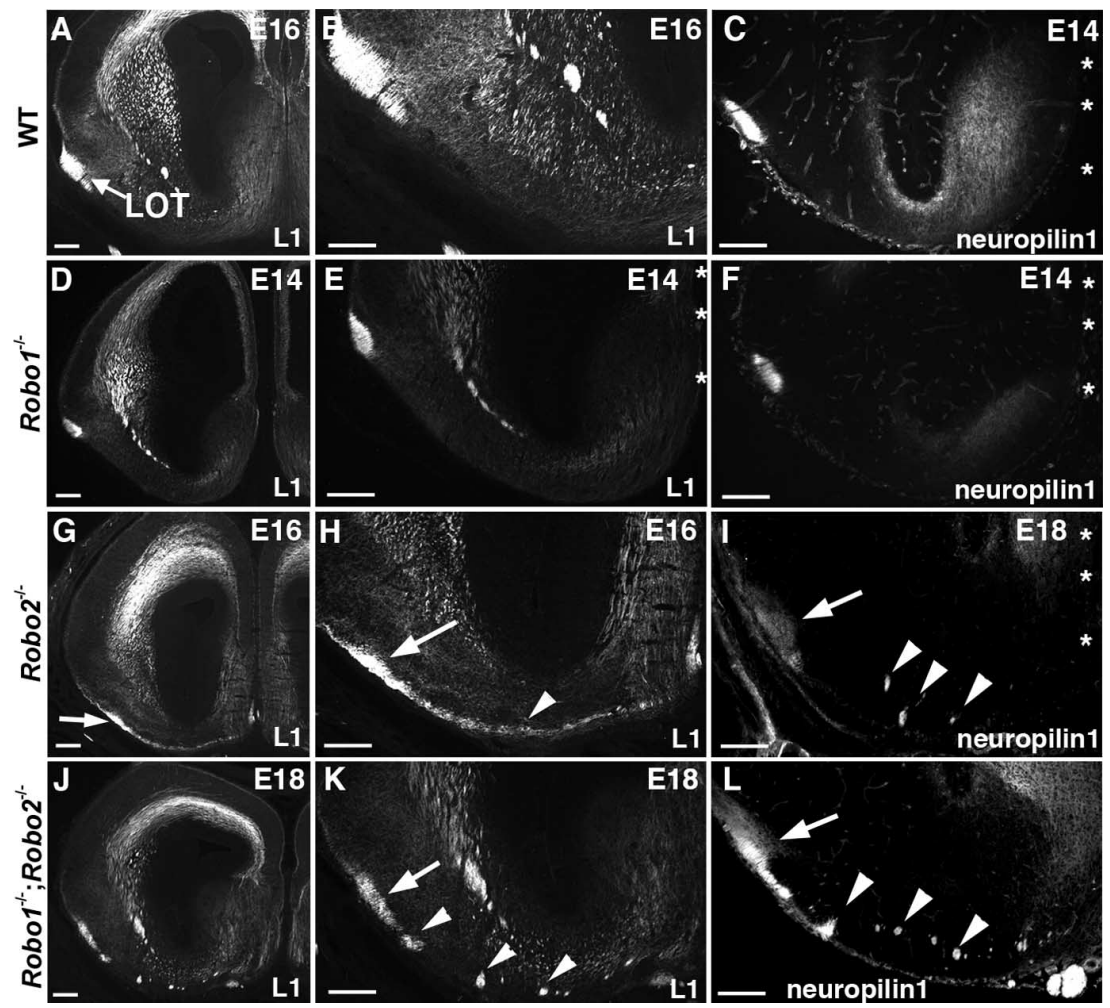

E16

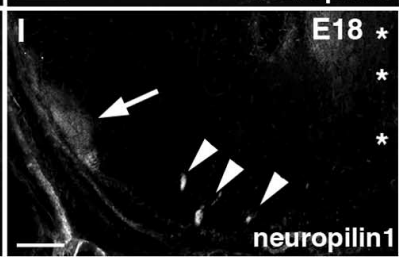

Figure 5. $L 1$ and Neuropilin 1 expression in Robo 1 and Robo2 single and double mutants. $A-L$, Forebrain coronal sections were immunolabeled with anti-L1 $(\boldsymbol{A}, \boldsymbol{B}, \boldsymbol{D}, \boldsymbol{E}, \boldsymbol{G}, \boldsymbol{H}, \boldsymbol{J}, \boldsymbol{K})$ and anti-neuropilin-1 $(\boldsymbol{C}, \boldsymbol{F}, \boldsymbol{I}, \boldsymbol{L}) \cdot \boldsymbol{A}-\boldsymbol{F}$, In E16 $(\boldsymbol{A}, \boldsymbol{B})$ and E14 ( $\boldsymbol{C}$ ) wild-type (WT) or Robo $1^{-/-}$mice $(\boldsymbol{D}-\boldsymbol{F})$, the $L 0 T$ is positioned laterally at a distance from the midline (asterisks in $\left.\boldsymbol{C}, \boldsymbol{E}, \boldsymbol{F}, \boldsymbol{I}\right) . \mathbf{G}-\mathbf{I}$, In contrast, in Robo2 ${ }^{-1-}$ mutants, the L0T is thinner at E16 $(\boldsymbol{G}, \boldsymbol{H})$ and divided into multiple bundles (arrowheads) at E18 (I). J-L, In E18 coronal sections in Robo1 $1^{-1-} ; R o b 02^{-1-}$ mice, the LOT is totally disrupted (arrowheads) and spreads all over the ventral forebrain. Nevertheless, there is still a subset of $O B$ axons at their correct position (arrows). Scale bars: $A, D, G, J, 150 \mu \mathrm{m} ; \boldsymbol{B}, \boldsymbol{C}, \boldsymbol{E}, \boldsymbol{F}, \boldsymbol{H}, \boldsymbol{I}, \boldsymbol{K}, \boldsymbol{L}, 225 \mu \mathrm{m}$. may act as guidepost cells (Hirata et al., 2001). Lot cells can be visualized with the monoclonal antibody mAb lot1 and migrate ventrally from the dorsal telencephalic vesicle to their final position (Sato et al., 1998; Tomioka et al., 2000). To determine er the observed LOT defects observed in Slit and Robo muied Robo2-deficient mice. Lot cells confined to the vicinity of the LOT are the most numerous between E14.5 and E16.5 (Sato et al., 1998). At these ages, LOT axons could be detected by antineuropilin-1 immunohistochemistry (Sugisaki et al., 1996) (Fig. (G). In Slit ${ }^{+-}$, as in wild-type mice, lot1-expressing cells were observed surrounding and/or enriched around neuropilin-1labeled LOT axons $(n=2$ ) (Fig. $8 A-C$ ). The same distribution of (Flit2 $2^{+/}$mice $(n=2)$ (Fig. (Slit2 mice, although the LOT was obvi(data not shown), the distribution of lot cells was not modified (Fig. $8 H$ ). Last, in Slit $1^{-/-}$;Slit2 ${ }^{-/-}$mice where the LOT was totally disrupted, with few axons still present at their norma position, lot cells were still concentrated at their proper location ( However, the density of lot1-positive cells was slightly decreased rostrally, near the ventral part of the $\mathrm{OB}$, where many misrouted LOT axons are found $(n=5 / 5)$ (Fig. $7 E-H)$. In E16 Robol mice (Fig. 9D-F) $(n=1)$, the same pattern was observed as in wild-type mice (Fig. 9A-C). In Robo $2^{-1-}$ mice, the distribution of lot cells appeared unchanged although the LOT was slightly perturbed, (Fig. 9G,H) $(n=5)$. In Robo1 ${ }^{-/-}$;Robo2 $2^{-/-}$mutant mice $(n=2)$, which exhibit the most striking defects, lot cells were not seen surrounding LOT axons displaced ventromedially, but were still concentrated at their normal lateral position (Fig. 9J-L). Thus, lot cells appear to migrate normally in Slit and Robo mutants, and the action of Slit and Robo on LOT axon pathfinding is likely to be direct.

\section{Discussion}

The first diffusible chemorepulsive activity in the vertebrate brain was identified in the rat septum and proposed to guide mitral cell axons (Pini, 1993). Later, we and others showed that this septum-derived repellent activity was caused by a combination of Slit1 and Slit2 that are both highly expressed in the septum from the beginning of LOT development ( $\mathrm{Li}$ et al., 1999; Nguyen Ba-Charvet et al., 1999, 2002). Nevertheless, some in vitro data using Robo-Fc proteins raised doubt on the role Robo receptors in the guidance of LOT axons (Patel et al., 2001) and direct evidence using Robo-function-blocking reagents was still lacking. Our current results show that Robol and Robo 2 are the major receptors, present on LOT axons that mediate Slit chemorepulsive activity in vitro and also in vivo. This represents the first direct evidence in vertebrates for a role for Robo receptors in slit-mediated axonal repulsion. This also confirms that 

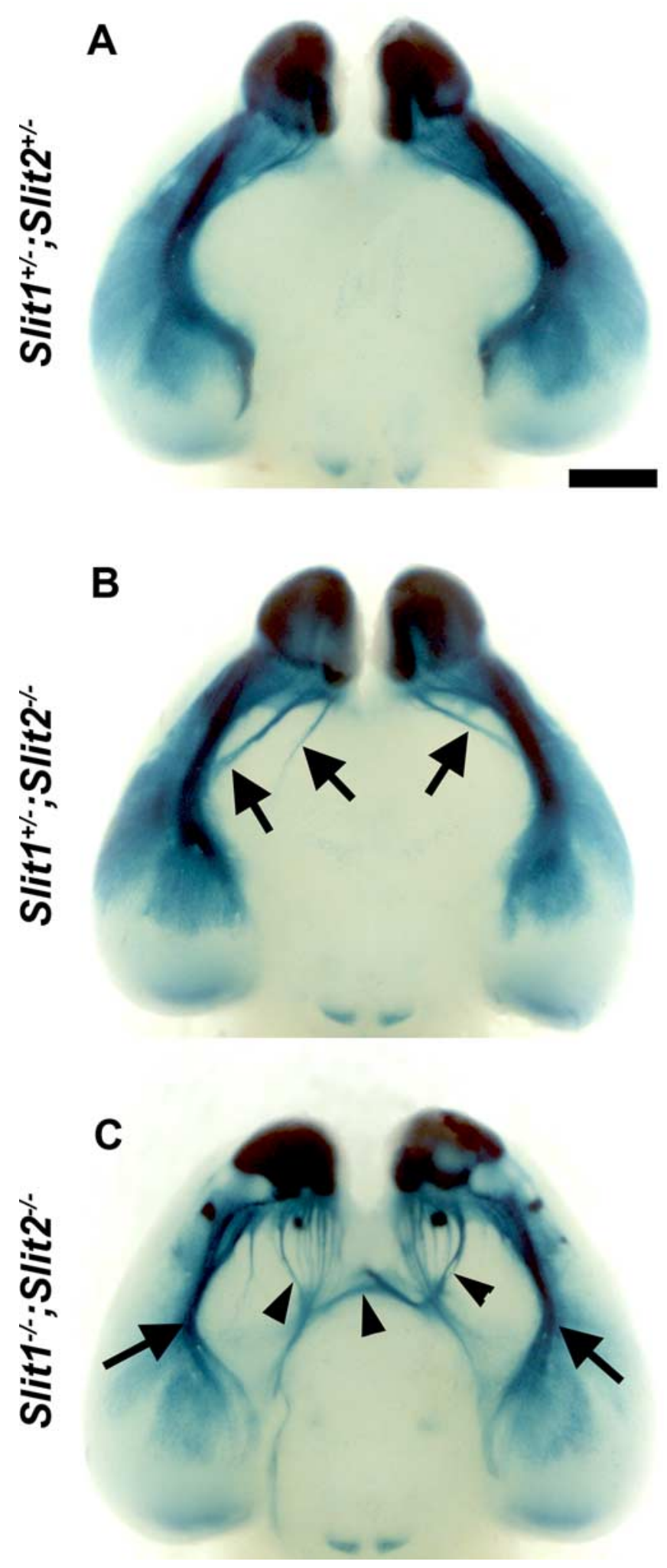

Figure 6. Ventral views from whole-mount X-Gal staining of Slit1;Slit2 mutant brains at E18.5. Slit1;Slit2 mice were mated with a gene-trap mouse in which $\beta$-galactosidase is expressed by most of the main $\mathrm{OB}$ axons. $\boldsymbol{A}$, The LOT extends caudally and laterally along the pial surface of the telencephalon, forming a single axon bundle in the Slit $1^{+/-} ;$Slit2 $2^{+/-}$brain. $B$, In Slit $1^{+/-} ;$Slit2 ${ }^{-/-}$mutants, some small bundles escape from the main LOT trajectory to extend ventrally (arrows). C, In Slit1 ${ }^{-1-} ;$ Slit2 ${ }^{-/-}$mutants, stray axons from the medial OB are marked and seem to cross the ventral midline (arrow heads). There still is an axon bundle along the normal LOT trajectory (arrows). Scale bar, $1 \mathrm{~mm}$.
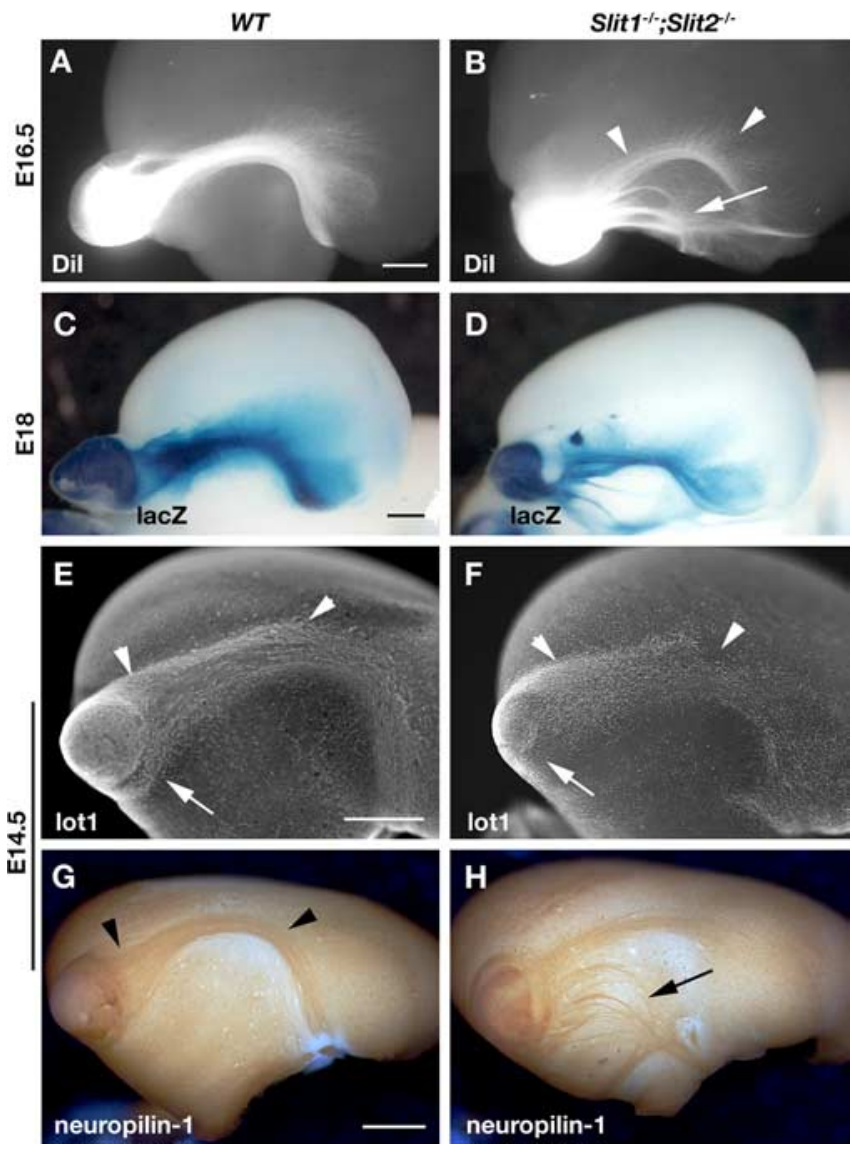

Figure 7. Lot cells and LOT axons in Slit-deficient mice. $\boldsymbol{A}-\boldsymbol{H}$, In toto labeling of the telencephalon of wild-type (WT) $(\boldsymbol{A}, \boldsymbol{C}, \boldsymbol{E}, \boldsymbol{G})$ or Slit1/Slit2 double mutants $(\boldsymbol{B}, \boldsymbol{D}, \boldsymbol{F}, \boldsymbol{H}) . \boldsymbol{A}, \boldsymbol{B}$, Dil labeling at E16.5. Although in WT $(\boldsymbol{A})$ LOT axons are tightly fasciculated, many medial $O B$ axons invade the ventral telencephalon in Slit mutants ( $\boldsymbol{B}$, arrow). However, axons from the lateral $O B$ have a normal lateral distribution ( $\boldsymbol{B}$, arrowheads). $\boldsymbol{C}, \boldsymbol{D}$, lateral views from whole-mount $X$-Gal staining of Slit1;Slit2 mutant brains at E18.5 (see Materials and Methods). The dorsal extent of LOT axons is similar in WT ( $\boldsymbol{C}$ and Slit mutants (D).E, $\boldsymbol{F}$, Lot-1 immunostaining reveals that the dorsoventral distribution of lot cells (arrowheads) is largely normal in E14.5 Slit mutants. However, the density of lot-1-expressing cells is slightly reduced rostrally, near the exit point of medial OB axons ( $\boldsymbol{F}$, arrow). $\boldsymbol{G}, \boldsymbol{H}$, LOT axon pathfinding defects at E14.5, visualized with antineuropilin-1 antibodies. In Slit mutants, LOT axons invade the ventral telencephalon (arrow) and do not stay lateral as in the WT brain (G, arrowheads). Scale bars, $500 \mu \mathrm{m}$.

Robo receptors play a major role in guiding forebrain axons in vertebrates (Miyasaka et al., 2005; Andrews et al., 2006).

Other studies proposed that the septum repellent and Slit proteins are not essential to guiding LOT axons, but only function in parallel with lot cells. Thus, the removal of the septum or the addition of a Robol ectodomain in whole-telencephalon organotypic cultures did not affect the projection of mitral cell axons (Hirata et al., 2001). Our results demonstrate that the distribution of lot1-expressing cells is not significantly perturbed in Slit1-, Slit2-, Slit1;Slit2-, or Robo1-, Robo2- and Robo1;Robo2deficient mice. Importantly, misrouted LOT axons do not appear surrounded or in contact with lot1-positive cells. This suggests that long-range guidance by Slit molecules and their receptors Robos is preponderant over short-range cues for guiding LOT axons. However, we cannot entirely rule out the possibility that lot cells contribute to the guidance of some LOT axons. First, in Slit1;Slit2 double-deficient mice, the number of lot-1 expressing cells is slightly reduced near the exit point of medial OB axons, suggesting that this subtle disruption of the distribution of lot cells might play a part in the ectopic projection of $\mathrm{OB}$ axons. 

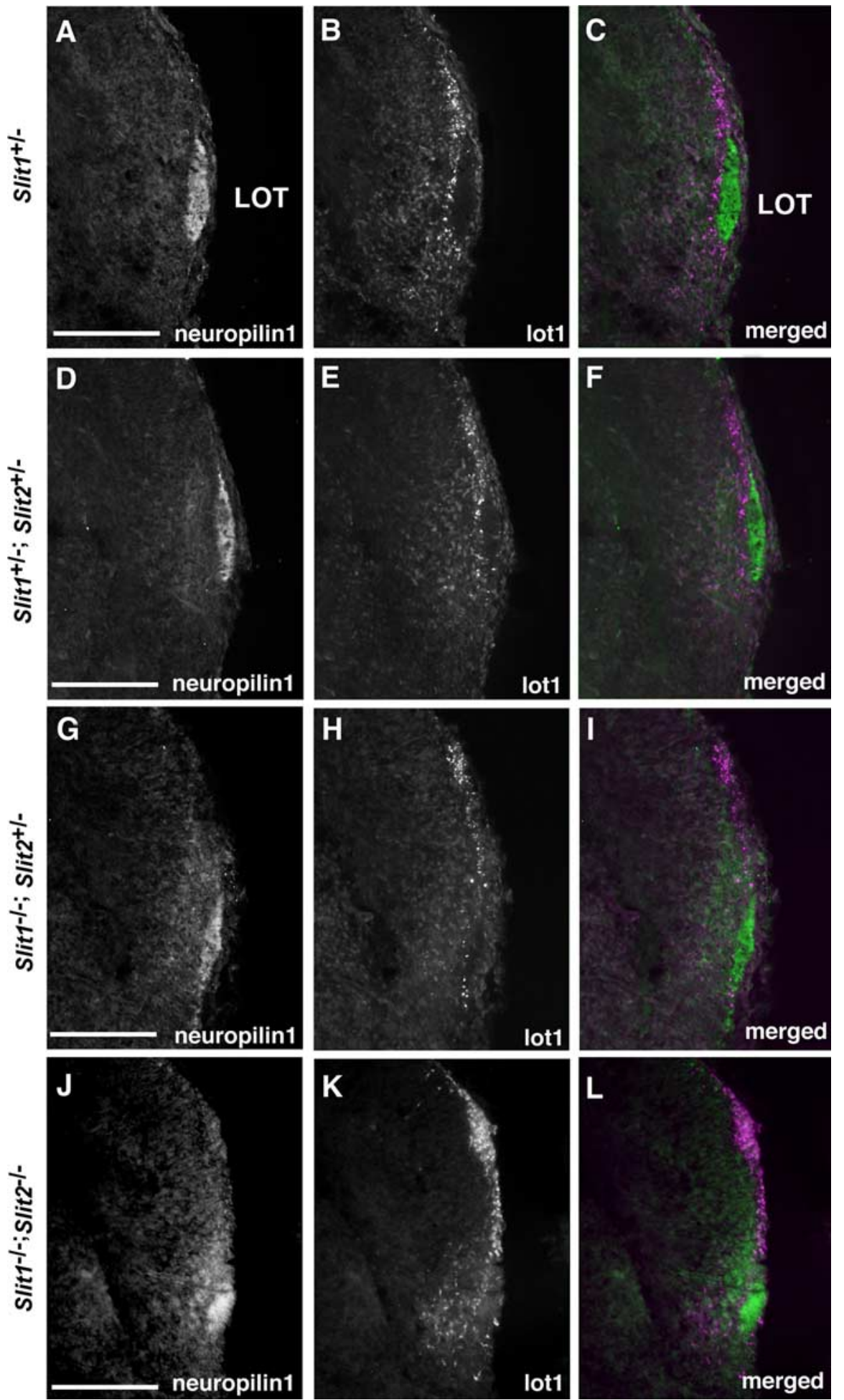

Figure 8. Lot cells in Slit-deficient mice. Coronal sections of E14.5 telencephalon were stained with anti-neuropilin1 (green) and mAb Lot1 (magenta) labeling the LOT and the lot cells, respectively. $\boldsymbol{A}-\boldsymbol{F}$, Lot cells surround the LOT in Slit $1^{+/-}(\boldsymbol{A}-\boldsymbol{C})$ and Slit $1^{+I-}$;Slit2 ${ }^{+I-}$ mice $(\boldsymbol{D}-\boldsymbol{F}) . \mathbf{G}-\mathbf{I}$, In contrast, in Slit1 ${ }^{-I-}$;Slit2 ${ }^{+I-}$ mice, the LOT is flattened along the surface, but the lot cells pattern is unchanged. $\boldsymbol{J}-\boldsymbol{L}$, The lot-cell pattern is similar in Slit $1^{-1-} ;$ Slit2 ${ }^{-1-}$ mice, although neuropilin1-positive LOT axons are completely defasciculated. Scale bars, $0.2 \mathrm{~mm}$.

Second, it has been shown previously that in deleted in colorectal cancer (DCC) mutant embryos, the perturbation of lot cell migration leads to defects of LOT axons pathfinding (Kawasaki et al., 2006). It is unlikely in this system that a direct effect of the DCC on the guidance of olfactory axons contributes to the mis- guidance, as netrin-1 does not exert any effect on $\mathrm{OB}$ axons in vitro (de Castro et al., 1999; Li et al., 1999). Third, we show here that a subset of LOT axons originating from the lateral $\mathrm{OB}$ still project along the normal LOT pathway along lot cells, and that medial axons are more affected. Non-cell-autonomous factors such as lot cells might be involved in this differential behavior of the lateral and medial OB axons. Together, these results suggest that the LOT contains different type of $\mathrm{OB}$ axons that may be guided by distinct molecules.

In addition to Slits and their Robos receptors, developing LOT axons have been proposed to be influenced by other longrange cues of the Semaphorin family. Mitral cell axons express both neuropilin-1 and neuropilin-2. In organotypic cultures, the olfactory epithelium secretes a repellent cue for OB axons (de Castro et al., 1999). This repulsive effect can be mimicked by cells secreting Sema3F, a secreted semaphorin expressed in the olfactory epithelium at the time of LOT development. Furthermore, Sema3B secreted by aggregates of COS cells is able to attract $\mathrm{OB}$ axons. Nevertheless, the analysis of the mice deficient for the class 3 semaphorin receptors neuropilin-1 (Kitsukawa et al., 1997) or neuropilin-2 (Chen et al., 2000) showed a totally normal LOT, which does not support a critical role for these semaphorins in LOT axon guidance in vivo. Last, in Robo- and Slit-deficient mice, the preferential growth of misrouted LOT axons toward the septum may be in part caused by the presence of still unidentified attractants released by the ventral telencephalon, whose activity could be unmasked in absence of slit/robo-mediated repulsion.

We and others have shown previously that the $\mathrm{N}$-terminal leucine-rich regions in Slit are sufficient to repel $\mathrm{OB}$ axons (Chen et al., 2001; Nguyen Ba-Charvet et al., 2001). More recently, in Drosophila, it has been found that the second leucinerich domain of Slit is necessary to trigger Robo signaling. We show that in mice, LRR2 is actually sufficient for binding to LOT axons and requires Robol and Robo2; it is also sufficient for binding to other Robo expressing forebrain axons (Lopez-Bendito et al., 2007). The finding that LRR2-hSlit1-AP or LRR2-hSlit2-AP binding on forebrain sections is apparently abolished in $\mathrm{Robo1}^{-/-} ; \mathrm{Robo2}^{-/-}$ mice strongly suggests that Robol and Robo 2 are the only receptors for Slit1 and Slit2 on these axons. Previous studies have shown that other extracellular proteins such as the glycosylphosphatidylinositol-anchored heparan sulfate proteoglycan glypican-1 also bind Slits (Liang et al., 1999; Ronca et al., 

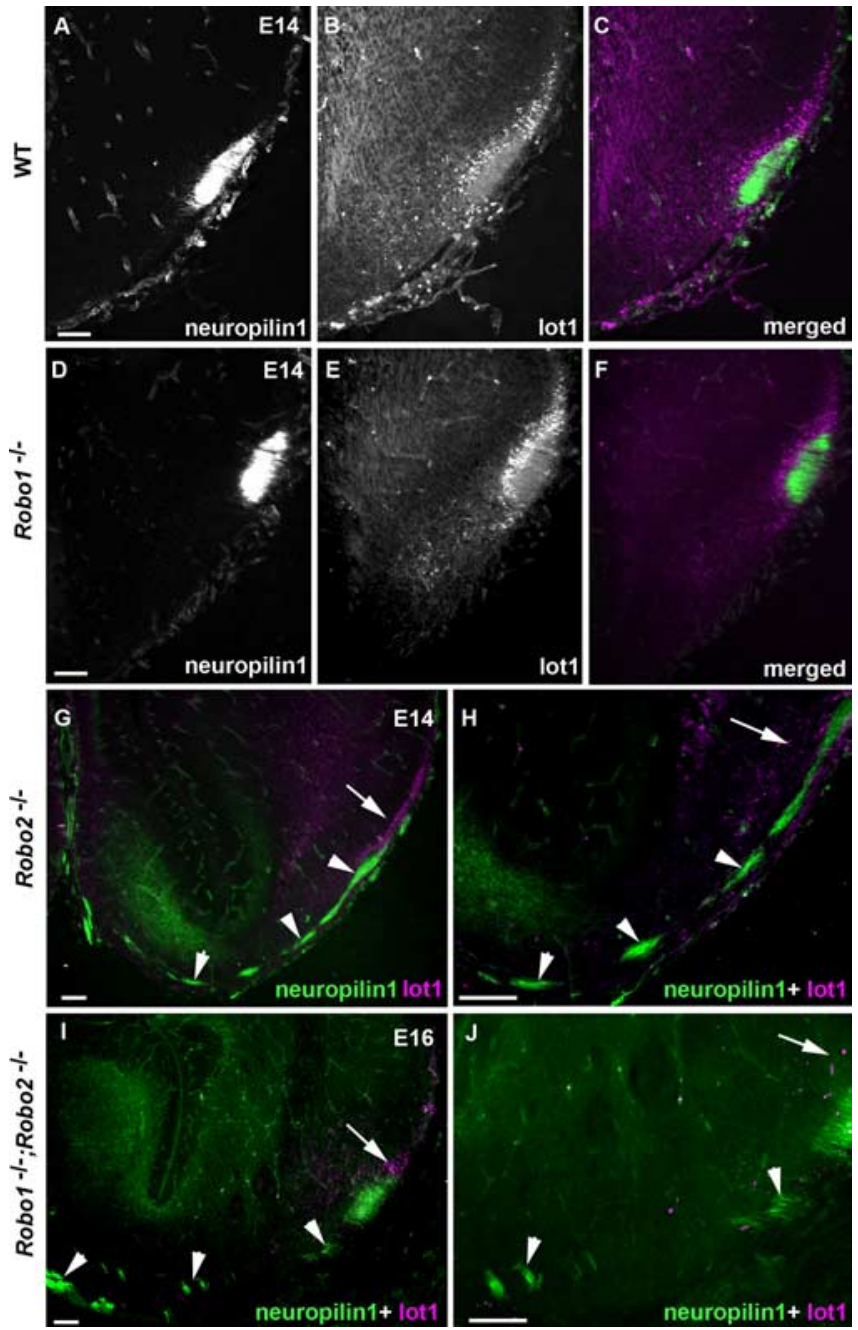

Figure 9. Lot cells in Robo-deficient mice. $\boldsymbol{A}-\boldsymbol{J}$, Coronal sections of E14 $(\boldsymbol{A}-\boldsymbol{H})$ or E16 $(\boldsymbol{I}, \boldsymbol{J})$ telencephalon were stained with anti-neuropilin1 (green) and mAb Lot1 (magenta). $\boldsymbol{A}-\boldsymbol{F}$, Lot cells surround the LOT in wild-type $(\boldsymbol{A}-\boldsymbol{C})$ and $R o b 01^{-1-}$ mice $(\boldsymbol{D}-\boldsymbol{F}) . \mathbf{G}-\boldsymbol{J}$, In contrast, in Robo2 $2^{-1-}(\boldsymbol{G}, \boldsymbol{H})$ and Robo1 ${ }^{-I-} ;$ Robo2 $2^{-I-}$ mutant mice $(\boldsymbol{I}, \boldsymbol{J})$, the LOT is flattened along the pial surface and highly defasciculated (arrowheads) whereas the lot cell position (arrow) is similar to wild-type. Ectopic ventral LOT axonal bundles ( $\boldsymbol{H}, \boldsymbol{J}$, arrowheads) do not contact lot1-expressing cells (arrow). Scale bars: $\boldsymbol{A}, \boldsymbol{D}, 60 \mu \mathrm{m} ; \boldsymbol{G}, \boldsymbol{I}, 80 \mu \mathrm{m} ; \boldsymbol{H}, \boldsymbol{J}, 95 \mu \mathrm{m}$.

2001). However, glypican-1 binds to the C-terminal fragment of Slit, which is dispensable for its chemorepulsive activity (Brose et al., 1999). Cell-surface heparan sulfate is also involved in vitro, in the repulsive activity of Slit on the postnatal migrating subventricular zone (Hu, 2001). Our results suggest that, in vivo, Slit directly binds to Robo receptors on embryonic forebrain axons, but do not exclude that heparan sulfate proteoglycans could still play a role in modulating Slit/Robo signaling in postnatal or adult forebrain neurons.

It has been shown previously that, as in Drosophila, there may be a Robo code for lateral positioning of commissural axons in mice (Long et al., 2004). Robol-expressing commissural axons are concentrated both in the ventral and lateral funiculi, whereas Robo2-expressing axons are mainly in the lateral funiculus. LOT axons are also organized according to a mediolateral pattern: early born mature mitral cells project their axons into the middle lamina of the LOT, whereas late-born immature mitral cells send their axons into the superficial lamina (Inaki et al., 2004). We observed that Robol is only expressed in the LOT until E15, whereas Robo2 is expressed in present in the all LOT axons, all along the development. Moreover, Robol is more highly expressed in a superficial subpopulation of Robo2-positive LOT axons (Fig. 1C). This suggests that Robo1 and Robo 2 are part of a complex molecular system required to build the laminar organization of the LOT.

In conclusion, the detailed molecular mechanism of LOT formation is very complex and still needs to be thoroughly analyzed. For example, the factors controlling the growth of LOT axons along the rostrocaudal axis still have to be identified. This behavior is not affected in Slit1;Slit2-deficient mice, nor in Robo1; Robo2-deficient mice. At later ages, LOT axons send collaterals branches to the olfactory cortex (Hirata and Fujisawa, 1999). These collateral branches are the only connections of mitral and tufted cell axons with the olfactory cortex. So far, only Anosmin-1, a secreted protein, defective in the X chromosomelinked form of Kallmann syndrome has been shown to promote the branching of OB axons (Soussi-Yanicostas et al., 2002). However, Slit proteins are also possible candidates because Slit2 regulates the branching of sensory axons from the dorsal root ganglia (Wang et al., 1999) and Slit1 the branching of pyramidal cell dendrites in the neocortex (Whitford et al., 2002). Unfortunately the possible branching activity of Slits on $\mathrm{OB}$ axons is difficult to assess in the Slit1;Slit2- or Robo1;Robo2-deficient mice, because the growth of LOT axons is very disturbed and these double mutants die at birth. Our results also indicate that some guidance cues act on all LOT axons, but a previous study (Zou et al., 2001) has clearly shown that the projection from the OB to the olfactory cortex is topographically organized and that mitral cells innervated by olfactory receptor neurons from distinct zones of the olfactory epithelium (expressing distinct olfactory receptors) project to distinct regions in the olfactory cortex. The factors that regulate the formation of this complex projection map remain unknown.

\section{References}

Andrews W, Liapi A, Plachez C, Camurri L, Zhang J, Mori S, Murakami F, Parnavelas JG, Sundaresan V, Richards LJ (2006) Robol regulates the development of major axon tracts and interneuron migration in the forebrain. Development 133:2243-2252.

Bedell VM, Yeo SY, Park KW, Chung J, Seth P, Shivalingappa V, Zhao J, Obara T, Sukhatme VP, Drummond IA, Li DY, Ramchandran R (2005) Roundabout 4 is essential for angiogenesis in vivo. Proc Natl Acad Sci USA 102:6373-6378.

Brose K, Bland KS, Wang KH, Arnott D, Henzel W, Goodman CS, TessierLavigne M, Kidd T (1999) Slit proteins bind Robo receptors and have an evolutionarily conserved role in repulsive axon guidance. Cell 96:795-806.

Chen H, Bagri A, Zupicich JA, Zou Y, Stoeckli E, Pleasure SJ, Lowenstein DH, Skarnes WC, Chedotal A, Tessier-Lavigne M (2000) Neuropilin-2 regulates the development of selective cranial and sensory nerves and hippocampal mossy fiber projections. Neuron 25:43-56.

Chen JH, Wen L, Dupuis S, Wu JY, Rao Y (2001) The N-terminal leucinerich regions in slit are sufficient to repel olfactory bulb axons and subventricular zone neurons. J Neurosci 21:1548-1556.

de Castro F, Hu L, Drabkin H, Sotelo C, Chédotal A (1999) Chemoattraction and chemorepulsion of olfactory bulb axons by different secreted semaphorins. J Neurosci 19:4428-4436.

Flanagan JG, Leder P (1990) The kit ligand: a cell surface molecule altered in steel mutant fibroblasts. Cell 63:185-194.

Grieshammer U, Ma L, Plump AS, Wang F, Tessier-Lavigne M, Martin GR (2004) SLIT2-Mediated Robo2 signaling restricts kidney induction to a single site. Dev Cell 6:709-717.

Hao JC, Yu TW, Fujisawa K, Culotti JG, Gengyo-Ando K, Mitani S, Moulder G, Barstead R, Tessier-Lavigne M, Bargmann CI (2001) C. elegans Slit acts in midline, dorsal-ventral, and anterior-posterior guidance via the SAX-3/Robo receptor. Neuron 32:25-38. 
Hirata T, Fujisawa H (1997) Cortex-specific distribution of membranebound factors that promote neurite outgrowth of mitral cells in culture. J Neurobiol 32:415-425.

Hirata T, Fujisawa H (1999) Environmental control of collateral branching and target invasion of mitral cell axons during development. J Neurobiol 38:93-104.

Hirata T, Fujisawa H, Wu JY, Rao Y (2001) Short-range guidance of olfactory bulb axons is independent of repulsive factor slit. J Neurosci 21:2373-2379.

Howitt JA, Clout NJ, Hohenester E (2004) Binding site for Robo receptors revealed by dissection of the leucine-rich repeat region of Slit. EMBO J 23:4406-4412.

$\mathrm{Hu} \mathrm{H}$ (1999) Chemorepulsion of neuronal migration by slit2 in the developing mammalian forebrain. Neuron 23:703-711.

$\mathrm{Hu} \mathrm{H}$ (2001) Cell-surface heparan sulfate is involved in the repulsive guidance activities of Slit2 protein. Nature Neurosci 4:695-701.

$\mathrm{Hu} \mathrm{H}$, Rutishauser U (1996) A septum-derived chemorepulsive factor for migrating olfactory interneuron precursors. Neuron 16:933-940.

Huminiecki L, Gorn M, Suchting S, Poulsom R, Bicknell R (2002) Magic roundabout is a new member of the roundabout receptor family that is endothelial specific and expressed at sites of active angiogenesis. Genomics 79:547-552.

Inaki K, Nishimura S, Nakashiba T, Itohara S, Yoshihara Y (2004) Laminar organization of the developing lateral olfactory tract revealed by differential expression of cell recognition molecules. J Comp Neurol 479:243-256.

Jen JC, Chan WM, Bosley TM, Wan J, Carr JR, Rub U, Shattuck D, Salamon G, Kudo LC, Ou J, Lin DD, Salih MA, Kansu T, Al Dhalaan H, Al Zayed Z, MacDonald DB, Stigsby B, Plaitakis A, Dretakis EK, Gottlob I, et al. (2004) Mutations in a human Robo gene disrupt hindbrain axon pathway crossing and morphogenesis. Science 304:1509-1513.

Kawasaki T, Ito K, Hirata T (2006) Netrin 1 regulates ventral tangential migration of guidepost neurons in the lateral olfactory tract. Development 133:845-853.

Kidd T, Brose K, Mitchell KJ, Fetter RD, Tessier-Lavigne M, Goodman CS, Tear G (1998) Roundabout controls axon crossing of the CNS midline and defines a novel subfamily of evolutionarily conserved guidance receptors. Cell 92:205-215.

Kitsukawa T, Shimizu M, Sanbo M, Hirata T, Taniguchi M, Bekku Y, Yagi T, Fujisawa H (1997) Neuropilin-semaphorin III/D-mediated chemorepulsive signals play a crucial role in peripheral nerve projection in mice. Neuron 19:995-1005.

Kolodkin AL, Levengood DV, Rowe EG, Tai YT, Giger RJ, Ginty DD (1997) Neuropilin is a Semaphorin III receptor. Cell 90:753-762.

Li HS, Chen JH, Wu W, Fagaly T, Zhou L, Yuan W, Dupuis S, Jiang ZH, Nash W, Gick C, Ornitz DM, Wu JY, Rao Y (1999) Vertebrate Slit, a secreted ligand for the transmembrane protein roundabout, is a repellent for olfactory bulb axons. Cell 96:807-818.

Liang Y, Annan RS, Carr SA, Popp S, Mevissen M, Margolis RK, Margolis RU (1999) Mammalian homologues of the Drosophila slit protein are ligands of the heparan sulfate proteoglycan glypican-1 in brain. J Biol Chem 274:17885-17892.

Long H, Sabatier C, Le M, Plump A, Yuan W, Ornitz DM, Tamada A, Murakami F, Goodman CS, Tessier-Lavigne M (2004) Conserved roles for slit and robo proteins in midline commissural axon guidance. Neuron 42:213-223.

López-Bendito G, Flames N, Ma L, Fouquet C, DiMeglio T, Chedotal A, Tessier-Lavigne M, Marin O (2007) Robol and Robo2 cooperate to control the guidance of major axonal tracts in the mammalian forebrain. $\mathrm{J}$ Neurosci, in press.

Marillat V, Cases O, Nguyen-Ba-Charvet KT, Tessier-Lavigne M, Sotelo C, Chédotal A (2002) Spatiotemporal expression patterns of slit and robo genes in the rat brain. J Comp Neurol 442:130-155.

Miyasaka N, Sato Y, Yeo SY, Hutson LD, Chien CB, Okamoto H, Yoshihara Y (2005) Robo2 is required for establishment of a precise glomerular map in the zebrafish olfactory system. Development 132:1283-1293.

Nguyen Ba-Charvet KT, Brose K, Marillat V, Kidd T, Goodman CS, TessierLavigne M, Sotelo C, Chédotal A (1999) Slit2-mediated chemorepulsion and collapse of developing forebrain axons. Neuron 22:463-473.

Nguyen Ba-Charvet KT, Brose K, Ma L, Wang KH, Marillat V, Sotelo C, Tessier-Lavigne M, Chédotal A (2001) Diversity and specificity of actions of Slit2 proteolytic fragments in axon guidance. J Neurosci 21:4281-4289.
Nguyen-Ba-Charvet KT, Plump AS, Tessier-Lavigne M, Chédotal A (2002) Slit1 and Slit2 proteins control the development of the lateral olfactory tract. J Neurosci 22:5473-5480.

Patel K, Nash JAB, Itoh A, Liu Z, Sundaresan V, Pini A (2001) Slit proteins are not dominant chemorepellents for olfactory tract and spinal motor axons. Development 128:5031-5037.

Pini A (1993) Chemorepulsion of axons in the developing mammalian central nervous system. Science 261:34-98.

Plump AS, Erskine L, Sabatier C, Brose K, Epstein CJ, Goodman CS, Mason C, Tessier-Lavigne M (2002) Slit1 and Slit2 cooperate to prevent premature midline crossing of retinal axons in the mouse visual system. Neuron $33: 219-232$.

Rajagopalan S, Vivancos V, Nicolas E, Dickson BJ (2000a) Selecting a longitudinal pathway: Robo receptors specify the lateral position of axons in the Drosophila CNS. Cell 103:1033-1045.

Rajagopalan S, Nicolas E, Vivancos V, Berger J, Dickson BJ (2000b) Crossing the midline: roles and regulation of robo receptors. Neuron 28:767-777.

Ronca F, Andersen JS, Paech V, Margolis RU (2001) Characterization of Slit protein interactions with glypican-1. J Biol Chem 276:29141-29147.

Sabatier C, Plump AS, Le M, Brose K, Tamada A, Murakami F, Lee EY, Tessier-Lavigne M (2004) The divergent robo family protein rig-1/ robo3 is a negative regulator of slit responsiveness required for midline crossing by commissural axons. Cell 117:157-169.

Saga Y, Yagi T, Ikawa Y, Sakakura T, Aizawa S (1992) Mice develop normally without tenascin. Genes Dev 6:1821-1831.

Sato Y, Hirata T, Ogawa M, Fujisawa H (1998) Requirement for earlygenerated neurons recognized by monoclonal antibody Lot1 in the formation of lateral olfactory tract. J Neurosci 18:7800-7810.

Schwob JE, Price JL (1984) The development of axonal connections in the central olfactory system of rats. J Comp Neurol 223:177-202.

Seeger M, Tear G, Ferres-Marco D, Goodman CS (1993) Mutations affecting growth cone guidance in Drosophila: genes necessary for guidance toward or away from the midline. Neuron 10:409-426.

Shipley MT, Ennis M (1996) Functional organization of olfactory system. J Neurobiol 30:123-176.

Simpson JH, Bland KS, Fetter RD, Goodman CS (2000a) Short-range and long-range guidance by slit and its robo receptors: a combinatorial code of Robo receptors controls lateral position. Cell 103:1019-1032.

Simpson JH, Kidd T, Bland KS, Goodman CS (2000b) Short-range and long-range guidance by slit and its robo receptors: Robo and Robo2 play distinct roles in midline guidance. Neuron 28:753-766.

Soussi-Yanicostas N, de Castro F, Julliard K, Perfettini I, Chédotal A, Petit C (2002) Anosmin-1, defective in the X-linked form of Kallmann syndrome, promotes axonal branch formation from olfactory bulb output neurons. Cell 109:217-228.

Suchting S, Heal P, Tahtis K, Stewart LM, Bicknell R (2005) Soluble Robo4 receptor inhibits in vivo angiogenesis and endothelial cell migration. Faseb J 19:121-123.

Sugisaki N, Hirata T, Naruse I, Kawakami A, Kitsukawa T, Fujisawa H (1996) Positional cues that are strictly localized in the telencephalon induce preferential growth of mitral cell axons. J Neurobiol 29:127-137.

Tomioka N, Osumi N, Sato Y, Inoue T, Nakamura S, Fujisawa H, Hirata T (2000) Neocortical origin and tangential migration of guidepost neurons in the lateral olfactory tract. J Neurosci 20:5802-5812.

Wang KH, Brose K, Arnott D, Kidd T, Goodman C, Henzel W, TessierLavigne M (1999) Biochemical purification of a mammalian Slit protein as a positive regulator of sensory axon elongation and branching. Cell 96:771-784.

Whitford KL, Marillat V, Stein E, Goodman CS, Tessier-Lavigne M, Chédotal A, Ghosh A (2002) Regulation of cortical dendrite development by SlitRobo interactions. Neuron 33:47-61.

Yuan SS, Cox LA, Dasika GK, Lee EY (1999) Cloning and functional studies of a novel gene aberrantly expressed in RB-deficient embryos. Dev Biol 207:62-75.

Zallen JA, Yi BA, Bargmann CI (1998) The conserved immunoglobulin superfamily member SAX-3/Robo directs multiple aspects of axon guidance in C. elegans. Cell 92:217-227.

Zou Z, Horowitz LF, Montmayeur JP, Snapper S, Buck LB (2001) Genetic tracing reveals a stereotyped sensory map in the olfactory cortex. Nature 414:173-179. 